\title{
ECOLOGICAL PROCESSES IN THE SUBARCTIC PACIFIC: IRON LIMITATION CANNOT BE THE WHOLE STORY
}

By Charles B. Miller, Bruce W. Frost, Beatrice Booth, Patricia A. Wheeler, Michael R. Landry, and Nicholas Welschmeyer

\section{$\mathrm{S}$} TRETCHING ACROSS the Pacific between $45^{\circ} \mathrm{N}$ and the coast of Alaska (Fig. 1) is an oceanic region referred to as subarctic. It is part of a broader oceanic region in which major phytoplankton nutrients (nitrate, phosphate, and silicate) apparently are never depleted from the surface layer. Persistently high nutrient concentrations are found along the entire eastern edge of the Pacific with westward extensions in the subarctic and along the equator and with eastward extensions through Drake Passage and then around the globe south of $35^{\circ} \mathrm{S}$ (Reid, 1962). Ecological relationships vary dramatically along this nutrient-replete belt, and assembly of a complete comparative ecology for all of its distinctive parts has only begun.

Martin (1990; 1991, this issue) has opened a new chapter in this analysis by suggesting that limited availability of soluble iron may be a common factor preventing major nutrient depletion throughout the nutrient-replete belt. The initial observations leading to this suggestion (Martin and Fitzwater, 1988; Martin et al., 1989) were made in the subarctic Pacific, which immediately stimulated our interest as workers in the subarctic Pacific Ecosystem Research (SUPER) Program. Although the testing of Martin's hypothesis is still in an early phase (Banse, 1990; Martin et al., 1990), it is an attractive idea. It is one of several candidate explanations for the dominance of subarctic Pacific phytoplankton by cells of very small size. Given a flora composed of small cells, most other observations on subarctic Pacific ecology fit into a sensible, logical scheme. Perhaps similar schemes can be found for other sectors of the highnutrient belt. Iron limitation, if it proves impor-

C.B. Miller and P.A. Wheeler, College of Oceanography, Oregon State University, Corvallis, OR, 9733I, USA. B.W. Frost and B. Booth, School of Oceanography, University of Washington, Seattle, WA, 98195, USA. M.R. Landry, Department of Oceanography, University of Hawaii. Honolulu. HI, 96822, USA. N. Welschmeyer, Moss Landing Marine Laboratories, Moss Landing, CA, 95039, USA tant, can be only one facet of full understanding for pelagic ecosystem processes.

\section{The Subarctic Pacific Habitat}

The subarctic Pacific shares a feature with river estuaries. Its upper layer is diluted with freshwater (Fig. 2), which stabilizes the water column and prevents rapid vertical exchange through the halocline at 100-200 m. It differs in this from the subarctic North Atlantic, where small vertical density differences poise the water column for convective mixing with small changes in surface properties. The Pacific retains its freshened surface because it is colder on average, which lessens evaporation. It is colder because it has smaller input of subtropical water from the south. Warren (1983), in a simple analysis, attributes this to the lack of a cold northern basin (an equivalent to the Norwegian Sea) and a difference in the patterns of surface wind. The fundamental cause is not the velocity of the winds, which is sufficient to produce strong winter storm activity (cover photo, this issue), but that the pattern of windstress curl (from cross-wind gradients and turning of the large-scale wind) changes sign farther south in the eastern North Pacific than in the eastern North Atlantic.

Lack of deep winter mixing in the subarctic Pacific prevents seasonal elevation of surface nutrients to concentrations matching those of the subhalocline layers, which is $\sim 45 \mu \mathrm{M}$ in nitrate. Breakdown of seasonal thermal stratification in late winter allows mixing of the surface layer with the zone between the seasonal thermocline $(\sim 35$ $\mathrm{m})$ and the halocline. This intermediate layer receives about $300 \mathrm{mmol} \mathrm{NO}_{3} \mathrm{~m}^{-2} \mathrm{yr}^{-1}$, according to estimates of vertical advection and diffusion in the halocline (Miller and others, unpublished data). Thus, the productive surface layer receives nutrient intermittently, mostly in February and March, reaching concentrations as great as $17 \mu \mathrm{M}$ $\mathrm{NO}_{3}$ by spring but with considerable interannual variation. Phytoplankton uptake from April to October reduces that by $<10 \mu \mathrm{M}$, occasionally to
$P$

nutrient concentrations

are found along the

entire eastern edge of

the Pacific with

westward extensions

in the subarctic . . 


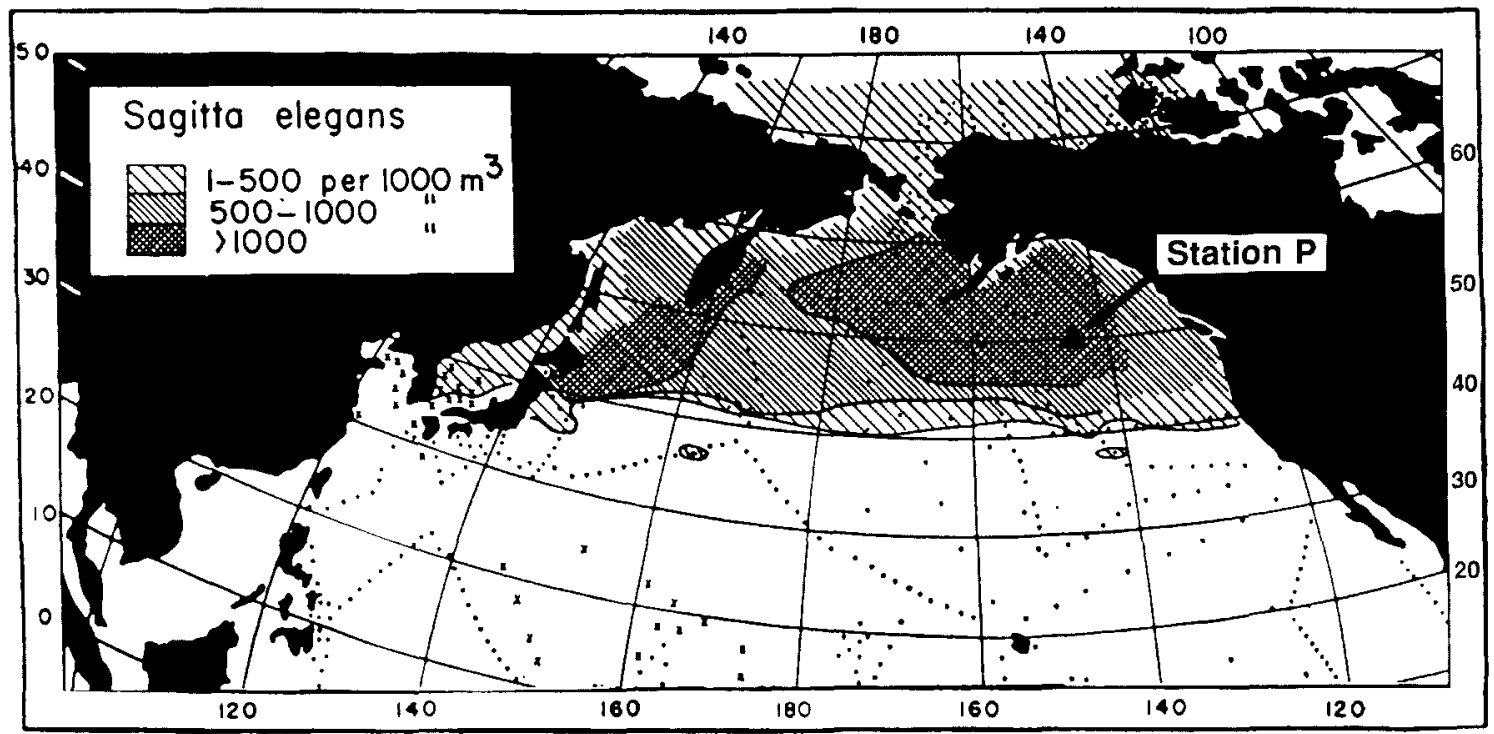

Fig. 1: Delineation of the subartic region of the North Pacific Ocean by the distribution of Sagitta elegans, a chaetognath (after Bieri, 1959). The subarctic Pacific is both a hydrographic feature and a biogeographic province. Station P in the southern Gulf of Alaska was formerly occupied by Canadian weatherships and was the site of most of the SUPER Program studies.

\section{Not only do plant}

stocks stay constant through the winter, they stay roughly constant all year long.
6 or $7 \mu \mathrm{M}$ (Fig. 8B). Constrained deep mixing also prevents flushing of the euphotic zone with large volumes of phytoplankton-free deep water so that phytoplankton stocks can remain high throughout the winter (Fig. 3). In the subarctic North Atlantic, the few winter observations available suggest that phytoplankton stock measured as chlorophyll-a ( $\mathrm{Chl}-\mathrm{a})$ concentration is reduced to $<0.1 \mathrm{mg} \mathrm{Chl}-\mathrm{a} \mathrm{m}^{-3}$ (Parsons and Lalli, 1988).

\section{Subarctic Pacific Ecology}

Absence of seasonal phytoplankton blooms is an ecologic signature of the subarctic Pacific. This was amply demonstrated by many years of data (Fig. 3) collected from Canadian weatherships on patrol at Ocean Station P $\left(50^{\circ} \mathrm{N}, 145^{\circ} \mathrm{W}\right)$. Not only do plant stocks stay constant through the winter, they stay roughly constant all year long. This has had several explanations. all involving a dynamic balance between phytoplankton growth rates, which vary seasonally, and zooplankton grazing rates, which therefore must also change seasonally. One explanation involves peculiarities of the larger zooplankton. The dominant net-captured zooplankton in the euphotic zone are the large copepods Neocalanus plumchrus and Neocalanus flemingeri. These zooplankton spawn yolky eggs at depth in winter without feeding (Miller and Clemons, 1988), supplying early copepodites to the surface layers in advance of the spring increase in phytoplankton production rates. Heinrich $(1957,1962)$ first suggested that the increased grazing capacity of these copepods as they grow through the spring allows them to keep pace with increasing plant growth, thus imposing "balance" on the phytoplankton stock. Heinrich con-

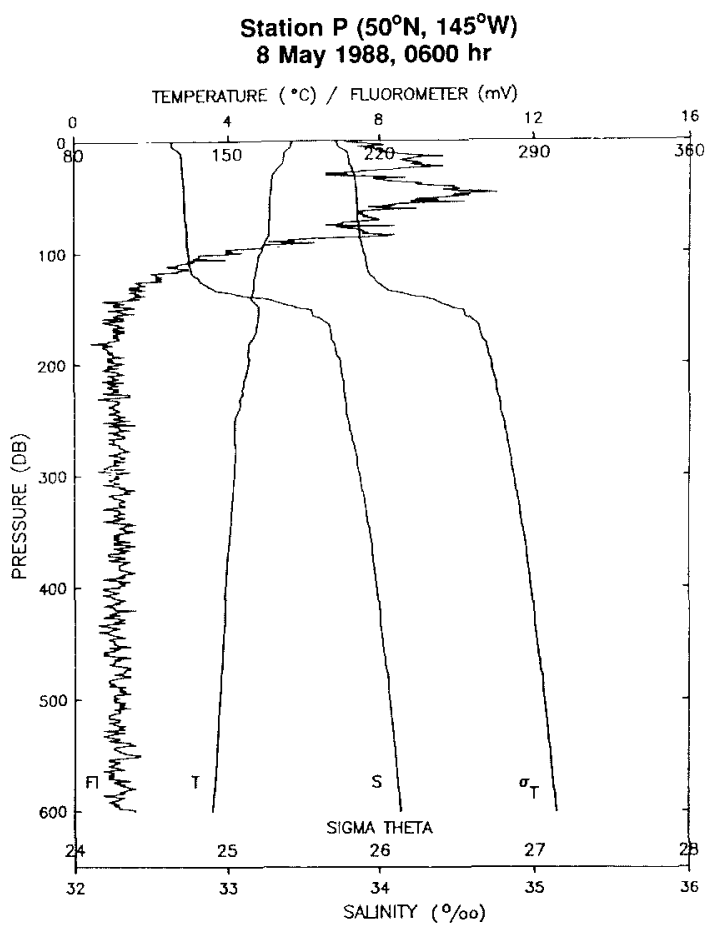

Fig. 2: Salinity $(S)$, temperature $(T)$, density $\left(\sigma_{T}\right)$, and stimulated fluorescence (Fl) profiles from Ocean Station P in the Gulf of Alaska, May 1988. The halocline from 110-170 m constrains mixing between the surface and deep layers. The fluorometer output (arbitrary millivolt units) shows that phytoplankton are strongly restricted to the surface laver.

trasted this with the North Atlantic case where the dominant macrozooplankter is Calanus finmarchicus, a copepod that only reproduces sig- 


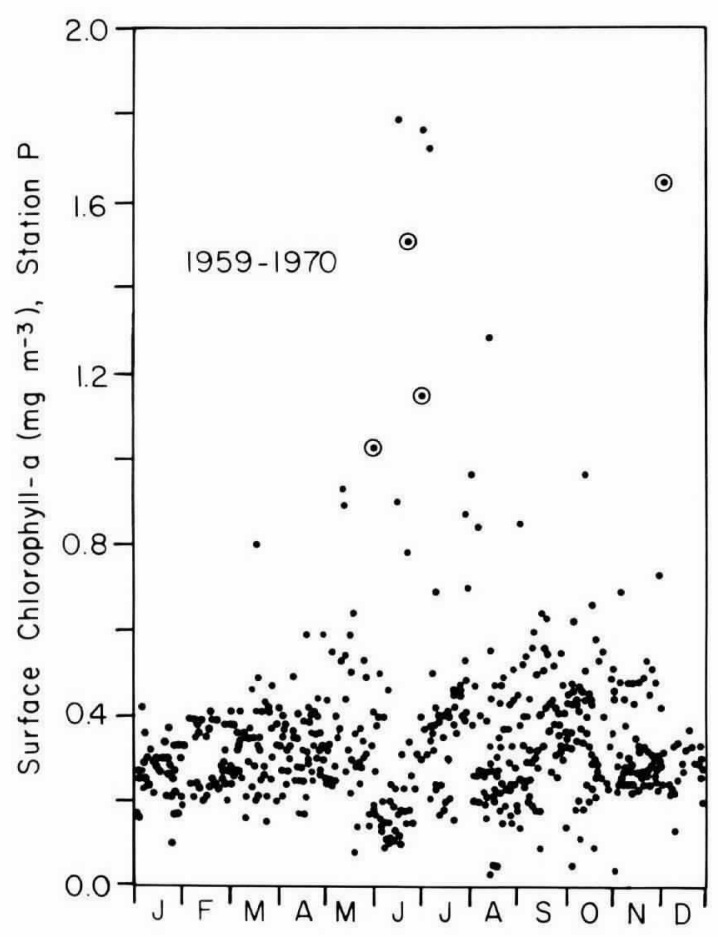

Fig. 3: Cumulative chlorophyll-a data from Ocean Station P. Scale extends only to $2.0 \mathrm{mg} \mathrm{m}^{-3}$. Four circled points are all the values over $1.0 \mathrm{mg} \mathrm{m}^{-3}$ from 1970-1976.

nificantly when food is abundant in surface layers (Smith, 1990). This creates a lag between phytoplankton growth and grazer response, which allows spring blooms and nutrient depletion. Heinrich characterized this system as "unbalanced."

The SUPER Program has tested that explanation (Miller and SUPER Group, 1988), showing that the spring stock of large copepods is not large enough, given the rate at which they feed and the rate of phytoplankton growth, to sustain balance. In fact, Neocalanus spp. appear not to be primarily herbivorous because there is not enough plant material in their guts at any time (Dagg and Walser, 1987) to sustain their respiration and observed growth (Miller and Nielsen, 1988).

Elimination of the life history-based "major grazer hypothesis" led us to consider microzooplankton, specifically heterotrophic protists, as the most likely source of grazing control of phytoplankton stocks. On our first expeditions, Booth and Horner (unpublished data) observed large numbers of very small $(\sim 5 \mu \mathrm{m})$ heterotrophic flagellates, substantial numbers of aloricate oligotrichous ciliates, and some larger $(\sim 40 \mu \mathrm{m})$ mixotrophic ciliates including Laboea sp. Such microheterotrophs are capable of population increase at higher rates, up to five doublings per day (Banse, 1982; Fenchel, 1982; Goldman and Caron, 1985), than phytoplankton, which are limited to about two doublings per day. This is because they can feed around the clock, which photoau- totrophs cannot do, and because their prey organisms handle all small-molecule syntheses, saving them costly chemical work. Thus, with their population-increase rates responding to phytoplankton abundance, they can rapidly catch up to any rise in phytoplankton stock above a feeding threshold level.

Pelagic microheterotrophs are mostly very small, certainly smaller than the larger forms among the phytoplankton. Many species of diatoms and dinoflagellates exceed $50 \mu \mathrm{m}$, and (ignoring giants such as the tropical Ethmodiscus rex) $200-\mu \mathrm{m}$ cells are common and much larger than microheterotrophs. Thus, grazing control of phytoplankton stock by microheterotrophs depends upon dominance of the flora by very small species. Larger phytoplankton must be controlled by other processes. In the subarctic Pacific, it is typical for $>90 \%$ of phytoplankton biomass to be in cells $<10 \mu$ m diameter (Booth, 1988) (Fig. 4). Larger phytoplankton are present (Clemons and Miller, 1984), but they are only a small proportion of the flora. The mechanism for their control is not clear, but Martin et al.'s (1989) experiment with iron addition suggests that iron limitation may slow their growth enough to allow control by macrozooplankton grazers. Selection for small size by a limiting trace metal has been explained in detail by Morel et al. (1991, this issue). Dominance of small phytoplankton results in a food web (Fig. 5) with one or several trophic steps involving small grazers, which are in turn the main food of particle-feeding macrozooplankton. Because microheterotrophs can switch to a bacterial diet, a microbial loop (dissolved organic matter to bacteria to microheterotrophs) may stabilize trophic relationships in the system, keeping small
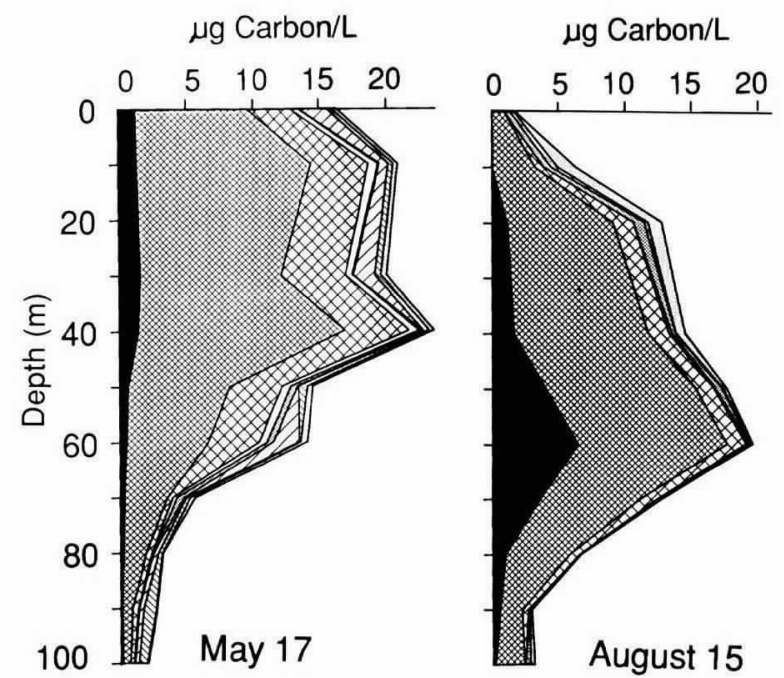

Fig. 4: Vertical and size distribution data for phytoplankton at Ocean Station $P$ in two seasons of 1984. Most cells $<2 \mu m$ were Synechococcus spp. Most phytoplankton biomass is in cells $<10 \mu \mathrm{m}$ diameter. Redrawn from Booth (1988).

... grazing control of

phytoplankton stock by

microheterotrophs

depends upon

dominance of the flora

by very small species.

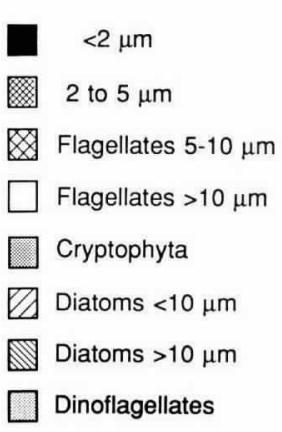




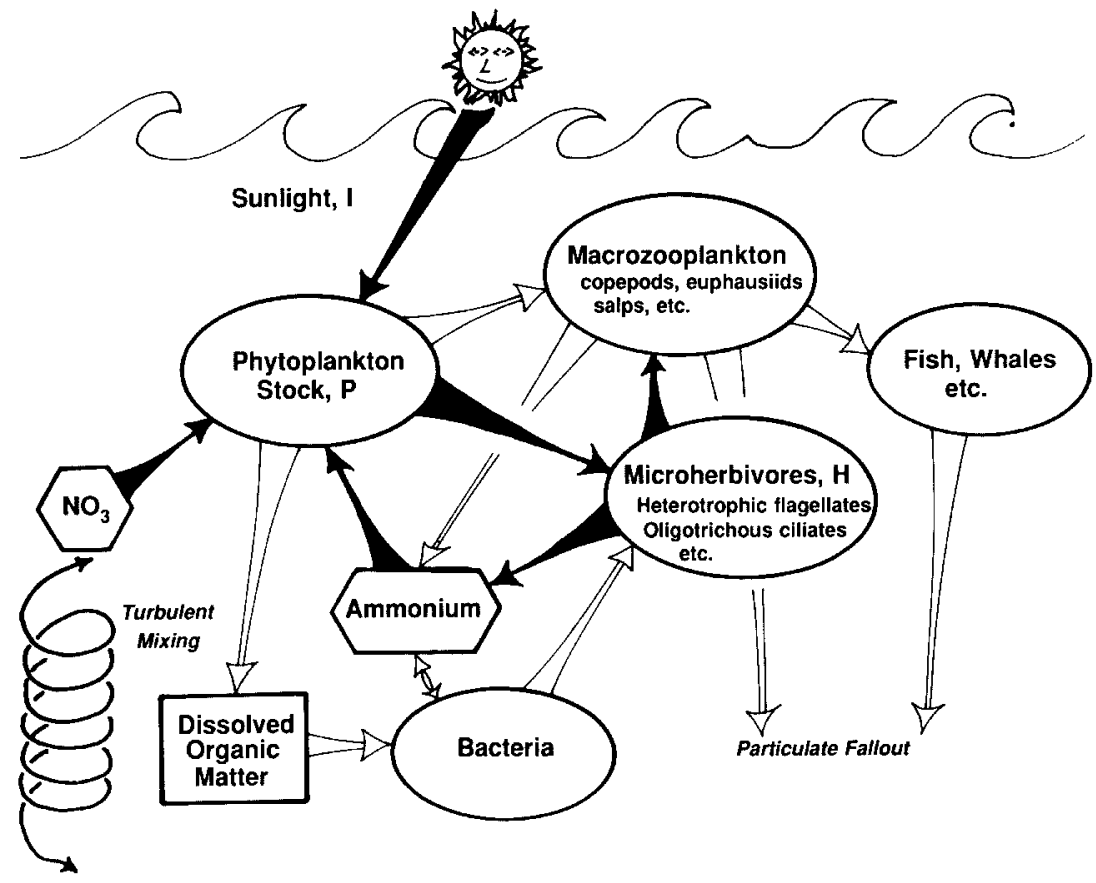

Fig. 5: Diagram of principal food web connections in the subarctic Pacific. Transfers of energy (and matter) are represented by arrows. Solid black arrows are transfers explicitly represented in the SUPER synthesis model. Open arrow's represent other transfers that stabilize the system (i.e., herbivory by macrozooplankton and the microbial loop) or return matter to outside the system (i.e., particulate fallout). Some transfers, such as contributions of fish to ammonium, have been left out to simplify, the diagram.

grazers present and active when phytoplankton are reduced for any reason.

The subarctic Atlantic may differ from the Pacific in two respects that lead to imbalance. First, iron limitation, if it operates, should be much less severe due to the generally closer proximity to land (but, see iron-flux data shown by Donaghay et al., 1991, this issue). Second, deep-winter mixing should clear the system of microheterotrophs as well as phytoplankton. It is possible that reestablishing the microheterotroph stock and its interaction with the phytoplankton requires time, with this lag allowing a phytoplankton bloom. It is more likely that the macrozooplankton have no dependable food source at the surface for their

Table 1

Relative contributions of micro- and macrograzers to removal of chlorophyll from the mixed layer in the Gulf of Alaska. The chlorophyll-budget technique is explained in the text and in Welschmeyer and Lorenzen (1985).

\begin{tabular}{|c|c|c|c|c|}
\hline \multirow[b]{2}{*}{ Expedition } & \multirow[b]{2}{*}{ Date } & \multirow[b]{2}{*}{ Number } & \multicolumn{2}{|c|}{$\begin{array}{c}\text { Mean } \\
\text { (of } \mathrm{N} \text { budget estimates) } \\
\text { contributions to grazing }\end{array}$} \\
\hline & & & Micro & Macro \\
\hline SUPER-3 & June 1987 & $(\mathrm{~N}=4)$ & $83 \%$ & $17 \%$ \\
\hline SUPER-4 & September 1987 & $(N=4)$ & $93 \%$ & $7 \%$ \\
\hline SUPER-5 & May 1988 & $(N=4)$ & $70 \%$ & $30 \%$ \\
\hline SUPER-6 & August 1988 & $(\mathrm{~N}=1)$ & $82 \%$ & $18 \%$ \\
\hline
\end{tabular}

young (equivalent to the persistent microheterotroph stock of the Pacific), so they cannot reproduce before the phytoplankton stock rebuilds in spring. Their absence during this season allows a bloom of large cells, despite their greater sensitivity to iron limitation. Heinrich's hypothesis is revived here in a modified form.

We term this understanding of production dynamics in the subarctic Pacific and of its distinction from the North Atlantic the "mixing and micrograzer hypothesis." Several aspects of it were tested on expeditions of the SUPER Program. We used phytoplankton pigment budgets (Welschmeyer and Lorenzen, 1985) to determine the relative impacts of microheterotroph and macrozooplankton grazing on phytoplankton stocks. Pigment budgets are possible because a fraction of the breakdown products of chlorophyll survive digestion in most animals. For large grazers, these "phaeopigments" appear in fecal matter large enough to sink out of the water column. For microheterotrophs, the fecal matter remains dispersed in the euphotic zone where it is subject to photodegradation by a reaction of known quantum efficiency. Thus, large-grazer impact should be proportional to the sinking flux of phaeopigments measured by sediment traps, whereas smallgrazer impact is proportional to net near-surface phaeopigment increase plus phaeopigment destruction (quantum flux $\times$ phaeopigment concentration $\times$ photodegradation efficiency). Relative comparisons of these two sources of grazing (Table 1) show that microheterotrophs account for at least four-fifths of chlorophyll conversion, and thus, of total grazing. That agrees with the hypothesis.

For microheterotroph grazing to sustain balance, feeding rates on phytoplankton should be consistently of the same absolute magnitude as phytoplankton growth rates. Expressed as an equation, phytoplankton stock, $\mathrm{P}$, should change with time according to $\mathrm{dP} / \mathrm{dt}=(\mu-g) \mathrm{P}$, where $\mu$ is the growth rate and $g$ is the overall grazing rate (both in units of days ${ }^{-1}$ ). When there is balance, $(1 / \mathrm{P})(\mathrm{dP} / \mathrm{dt})=0=\mu-g$, so that $\mu \approx g$. To examine the relation of $\mu$ to $g$, we applied Landry and Hassett's (1982) dilution technique, which provides estimates of both growth and grazing. Filtered seawater is added to incubations of nearsurface seawater in varying amounts. Dilution produces increase in apparent per capita phytoplankton growth because microheterotroph grazing is reduced by increased spacing of both grazers and plant prey. Plots of apparent $\mu$ versus dilution fraction $(0=$ infinite dilution; $1=$ no dilution) give the grazing-free $\mu$ as $\mathrm{Y}$-intercept and $-g$ as slope. In the Gulf of Alaska in spring, $\mu$ and $-g$ alternated in dominance (Fig. 6), which is consonant with the sorts of variations in phytoplankton stock that were observed from day to day (Fig. 7). 


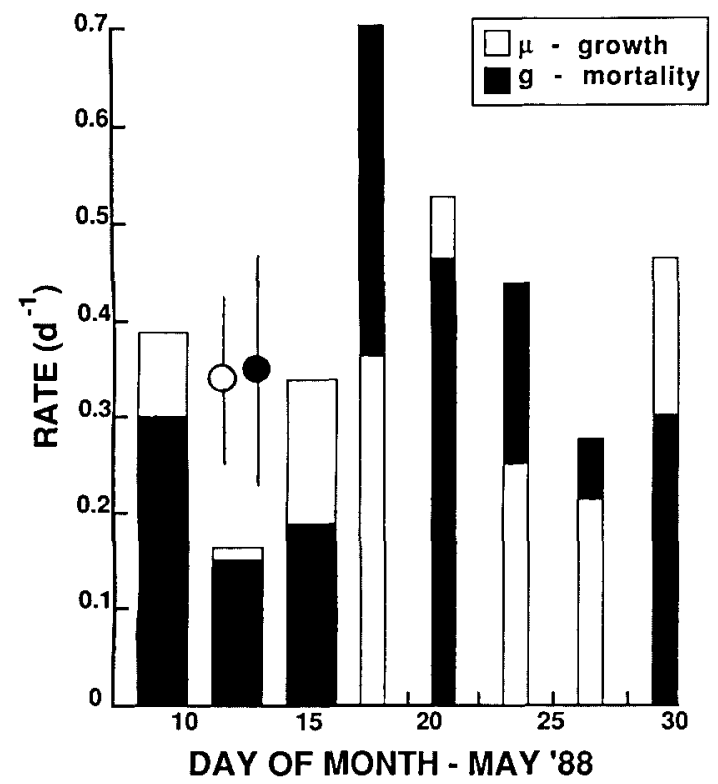

Fig. 6: Estimates of phytoplankton community growth and microzooplankton grazing rates from dilution experiments conducted during cruises to the Gulf of Alaska in May, 1988. Samples were collected from the surface mixed layer $(\sim 10 \mathrm{~m})$ and incubated on shipboard for 1 or 2 days under ambient temperature and light (shaded) conditions. Analyses based on chlorophyll a. Histograms indicate results of individual experiments. Circles indicate cruise-mean growth and grazing estimates (with $95 \%$ confidence limits).

In summary, once the phytoplankton are forced consistently to small cell size, a balanced system can develop in which stocks oscillate within relatively narrow limits because they are controlled by unicellular grazers with even higher population growth potential. It remains to show why such a system would always leave an excess of major nutrients. We term our explanation "the SUPER synthesis."

\section{The SUPER Synthesis}

Microheterotrophs are small, so they produce suspended fecal matter and, on short rations, they should die rapidly and decompose without sinking. Thus, their constituents should be recycled efficiently and their nitrogen recycled primarily as ammonium. Sufficient dissolved ammonium suppresses uptake of nitrate, which must be reduced before incorporation. Ammonium is available for immediate incorporation in proteins, and in some phytoplankton it directly interferes with the activity of nitrate reductase (Dortch, 1990). We have shown this suppression specifically for the subarctic Pacific by ${ }^{15} \mathrm{NO}_{3}$-uptake experiments (Wheeler and Kokkinakis, 1990). Phosphate is rapidly recycled too, although it doesn't have an associated redox change to aid in tracing the effect. Location of most nutrient recycling in the surface layer explains the persistence of substantial major nutrient levels throughout the year. Recycling holds the net annual nitrate use to $\sim 6 \mu \mathrm{M}$ in the upper 50 meters.

We represent this SUPER synthesis of the ecological relationships with a systems model based on that of Frost (1987). A simplified schematic food web (solid arrows in Fig. 5) is the basis of the model, which considers the following state variables.

Phytoplankton Stock,

$$
\begin{aligned}
& \mathrm{P}-\mathrm{mg} \text { organic carbon } \mathrm{m}^{-3} ; \\
& \mathrm{dP} / \mathrm{dt}=f_{1}(\mathrm{I}, \mathrm{P})-f_{2}(\mathrm{H}, \mathrm{P})
\end{aligned}
$$

where I is solar illumination

Phytoplankton Chlorophyll,

$$
\begin{aligned}
& \text { Ch- mg Chl-a m }{ }^{-3} \text {, } \\
& C h=(\text { seasonal constant }) \times \mathrm{P}
\end{aligned}
$$

Micrograzer Stock,

$$
\begin{aligned}
& \mathrm{H}-\mathrm{mg} \text { organic carbon } \mathrm{m}^{-3}, \\
& \qquad \mathrm{dH} / \mathrm{dt}=f_{3}(\mathrm{P})-f_{4}(\mathrm{H})
\end{aligned}
$$

$\left.\begin{array}{l}\text { Nitrate concentration }-\mu \text {-moles liter } \\ \text { Ammonium concentration }-\mu \text {-moles } \operatorname{liter}^{-1}\end{array}\right\}$

$$
\begin{aligned}
\mathrm{d}\left(\left[\mathrm{NO}_{3}\right]+\left[\mathrm{NH}_{4}\right]\right) / \mathrm{dt} & \\
= & f_{1}(\mathrm{I}, \mathrm{P}), \mathrm{NH}_{4} \text { preferred }
\end{aligned}
$$

Chlorophyll is used only for ready comparison to historical chlorophyll values, and it is derived from the phytoplankton stock by a carbon/chlorophyll ratio. Similarly, nitrate and ammonium taken up by phytoplankton or transferred to micrograzers are converted to organic carbon by a simple carbon/nitrogen ratio.

The physical habitat of the model is specified in terms of available photosynthetically active ra-

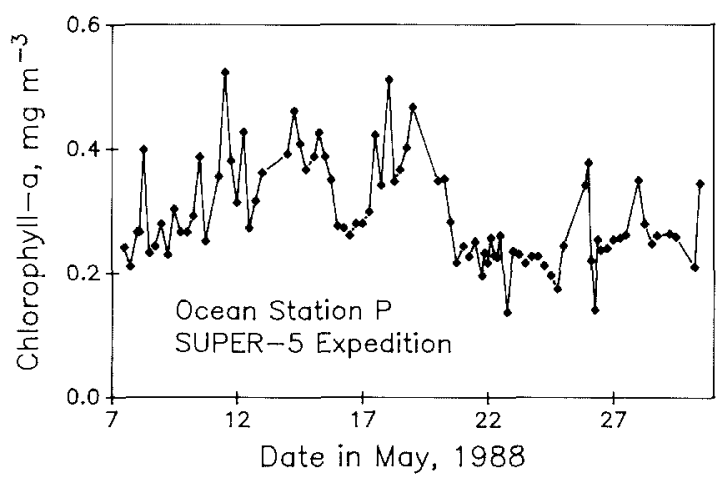

Fig. 7: Variability in mixed-layer chlorophyll-a concentration in the Gulf of Alaska during May 1988. Some variability is small-scale spatial difference; some is larger-scale temporal change. There are larger longer-term changes as well. The variation compares well to that shown by the process model.
Location of most

nutrient recycling in the surface layer explains the persistence of substantial major nutrient levels ... 

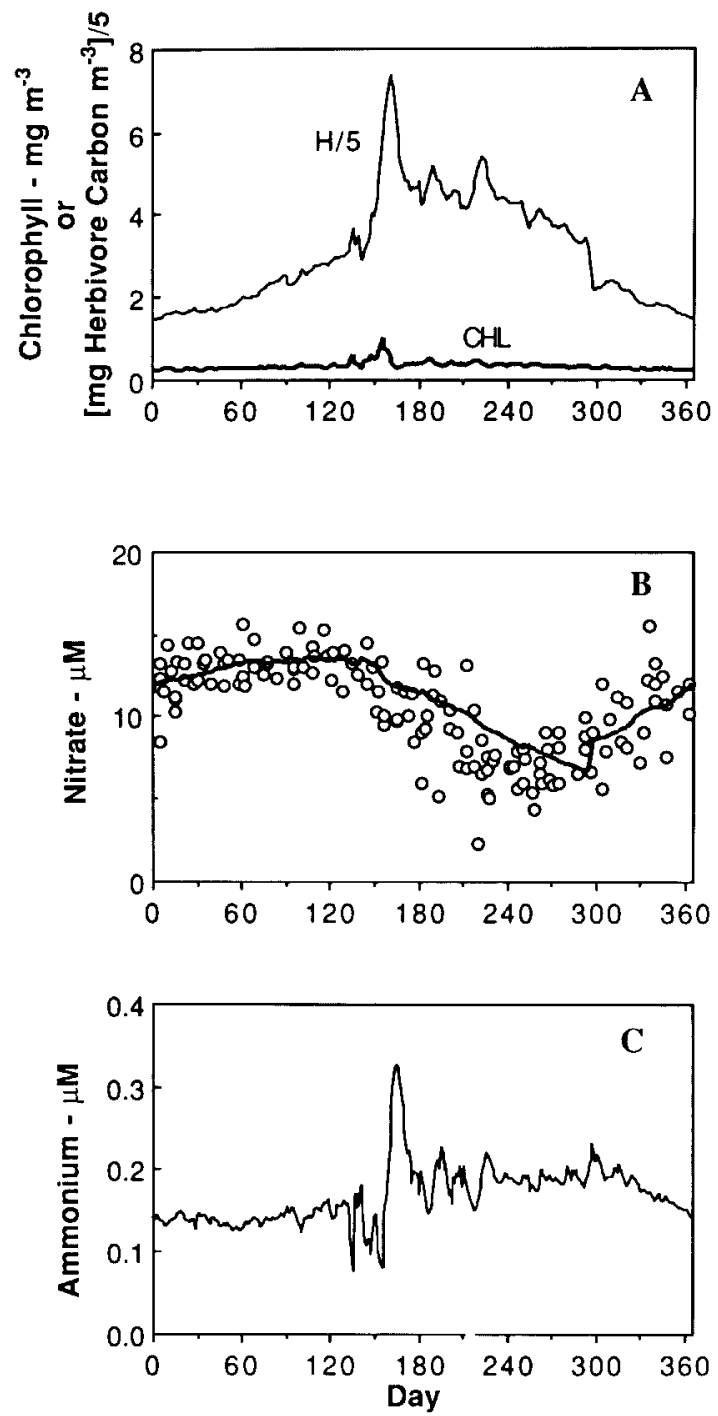

Fig. 8: Output of the ecosystem model of subarctic Pacific production processes. The model succeeds in several respects. 1) The total seasonal production (not shown) is approximately correct. 2) Chlorophyll-a $(A)$ is held in the range observed in the field and the short-term variability of chlorophyll is realistic, driven by variability in insolation. 3) Nitrate (B; circles are Ocean Station $P$ data from the weathership program; Parslow, 1981) utilization over the year is approximately as observed in the Gulf of Alaska. 4) Microzooplankton $(A)$ increase and vary through the spring and summer when phytoplankton production is high and are not greatly reduced in winter.

... capacity of the small dominant flora for dramatic response to relatively low illumination. through the middle layer is represented as turbulent, Fickian, diffusion, whose eddy diffusivity was varied seasonally $\left(0.1 \mathrm{~cm}^{2} \mathrm{sec}^{-1}\right.$ in summer, higher in late autumn through spring). Diffusivities were fitted to give reasonable property profiles at all times and to bring nitrate concentration back to the starting value at the end of the year. As done by Frost (1987), micrograzers are given a functional response (the relation between the per capita rate of ingestion of phytoplankton and the size of the phytoplankton stock) resembling that of tintinnids (Heinbokel, 1978). That is, massspecific ingestion at saturating phytoplankton availability was set at one body weight per day. An hyperbolic approach to this asymptote represented ingestion above a threshold phytoplankton stock of $5 \mathrm{mgC} \mathrm{m}^{-3}$. Growth efficiency was set conservatively at 30\% (Caron and Goldman, 1990 ) and mortality was made a hyperbolic function of micrograzer stock size.

Growth of phytoplankton in the model is set (or "limited") by either PAR or by nitrogen availability. However, because the parameters represent the subarctic Pacific, nitrogen-limitation never becomes important. Effectively, water-column production is controlled by light and plant standing stock, with stock established by growth and grazing. The relationship of photosynthesis to PAR in the model has a very steep slope, $\alpha$ $=5.0\left(\mathrm{mg}\right.$ carbon $\left.[\mathrm{mg} \mathrm{Chl-a}]^{-1} \mathrm{~m}^{-3}\right) /($ Einstein $\mathrm{m}^{-2}$ ). In situ primary productivity estimates made on SUPER cruises demonstrated this capacity of the small dominant flora for dramatic response to relatively low illumination. This must be conditioned on both ecological and evolutionary time scales by the strong day-to-day variability of PAR in the region.

Inorganic nitrogen is modeled as two components equivalent to nitrate and ammonium, somewhat as done independently by Fasham et

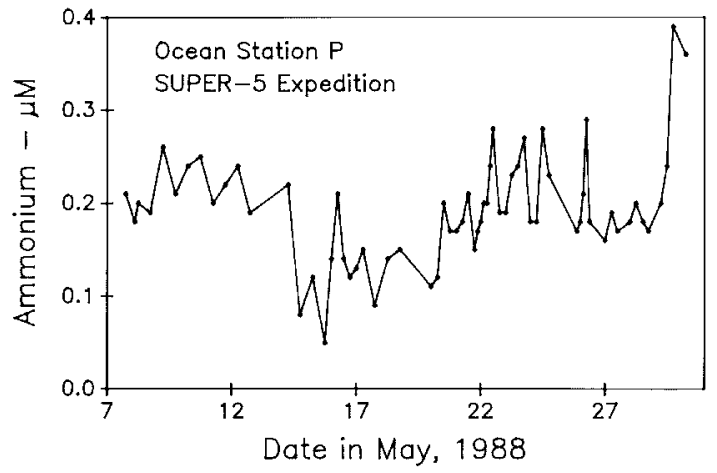

Fig. 9: Variability in mixed-layer ammonium concentration in the Gulf of Alaska during May 1988. Some variability is small-scale spatial difference: some is larger-scale temporal change. Diel variation is evident (Wheeler et al., 1989), and there are larger longer-term changes as well. 
al. (1990). Nitrate uptake was modeled as a function of photosynthetic activity limited by available light but reduced according to the amount of ammonium in the system (Fig. 8). When ammonium is available, uptake of ammonium replaces nitrate uptake, with the total nitrogen uptake set by the PAR-limited photosynthetic rate. The results of the model are daily time-series of the state variables.

The output of this ecosystem model reproduces the seasonal (Fig. 8) and (just as important) shortterm variabilities of phytoplankton stock (Fig. 7), nitrate and ammonium (Fig. 9) in the oceanic subarctic Pacific. Key results from SUPER field work are represented by the model. First, photosynthetic rates are principally limited by the available illumination. Even though growth of some rare large cells may be limited by iron availability, the dominant stock of small cells probably is not iron limited. Phytoplankton grow at the highest rates that the relatively cold temperatures and moderate illumination allow (Booth et al., 1988). Second, available nitrate (also phosphate) is not used in the course of the year because nitrogen as ammonium is efficiently recycled in the euphotic zone by the microheterotrophic grazing community.

\section{Conclusion}

All of the SUPER synthesis is consonant with Martin's (1991, this issue) suggestion that oceanic regions persistently rich in major nutrients are in some sense iron limited. Something sustains the dominance of very small phytoplankton in the subarctic Pacific. It could very well be the greater susceptibility of larger phytoplankton to iron limitation. Martin et al. (1989) showed that added iron shifts the dominant flora to larger cell sizes,

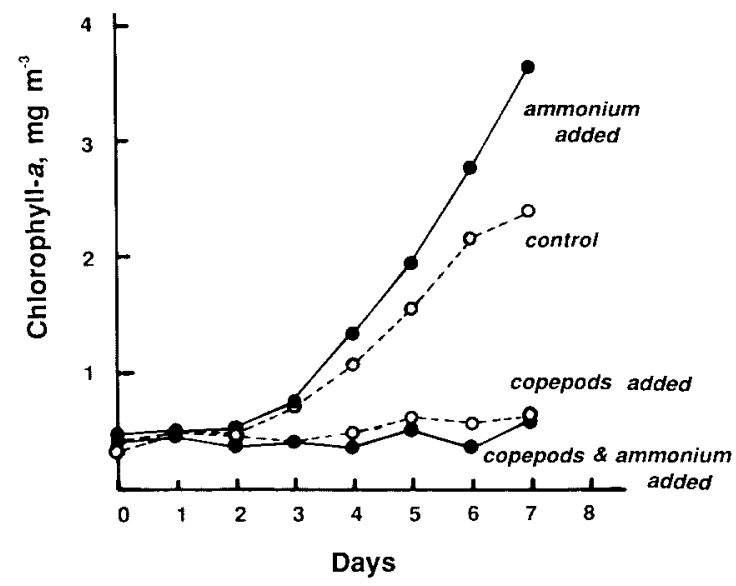

Fig. 10: Comparison of time courses for chlorophyll-a as a measure of phytoplankton stock in 60-liter containers with and without one fifth copepodite of Neocalanus plumchrus (large grazing copepod) per liter. Both treatments replicated with and without added ammonium. Redrawn from Landry and Lehner-Fournier (1988). particularly large diatoms. They also showed that iron had no immediate effect on the photosynthetic rates of the usual flora. If differential susceptibility of large and small phytoplankton to micronutrient limitation is involved, it must be backed by some grazing on large cells by macrozooplankton. Large cells are present, and their stocks could not be sustained without positive growth rates. Those must be balanced by some population loss. Landry and Lehner-Fournier (1988) have shown (Fig. 10) that at copepod densities somewhat above those observed in the field, growth of large phytoplankton can be balanced by their grazing, despite almost certain alleviation of iron limitation by inadvertent contamination. Precise quantification of all the important interactions remains on our agenda.

\section{Acknowledgements}

The SUPER Program has been supported by the US National Science Foundation. We thank the crews of $R / V$ Wecoma and $R / V$ Thompson for caring for us at sea.

\section{References}

Banse, K., 1982: Cell volumes, maximal growth rates of unicellular algae and ciliates, and the role of ciliates in the marine pelagial. Limnol. Oceanogr., 27, 1059-1071.

1990: Does iron really limit phytoplankton production in the offshore subarctic Pacific? Limnol. Oceanogr., $35,772-775$.

Bieri, R., 1959: The distribution of the planktonic chaetognatha in the Pacific and their relationship to the water masses. Limnol. Oceanogr., 4, 1-28.

Booth, B.C., 1988: Size classes and major taxonomic groups of phytoplankton at two locations in the subarctic Pacific Ocean in May and August, 1984. Mar. Biol., 97, 275286.

J. Lewin and C.J. Lorenzen, 1988: Spring and summer growth rates of subarctic Pacific phytoplankton assemblages determined from carbon uptake and cell volumes estimated using epifluorescence microscopy. Mar. Biol., 98, 287-298.

Caron, D.A. and J.C. Goldman, 1990: Protozoan nutrient regeneration. In: Ecology of Marine Protozoa, G.M. Capriulo, ed., Oxford Univ. Press, Oxford, 283-306.

Clemons, M.J. and C.B. Miller, 1984: Blooms of large diatoms in the oceanic, subarctic Pacific. Deep-Sea Res., 31, 8595.

Dagg, M.J. and W.E. Walser, 1987: Ingestion, gut passage, and egestion by the copepod Neocalanus plumchrus in the laboratory and in the subarctic Pacific Ocean. Limnol. Oceanogr., 32, 178-188.

Donaghay, P., P.S. Liss, R.A. Duce, D.R. Kester, A.K. Hanson, T. Villareal, N. Tindale and D.J. Gifford, 1991: The role of episodic atmospheric nutrient inputs in the chemical and biological dynamics of oceanic ecosystems. Oceanography, 4, 62-70.

Dortch, Q., 1990: The interaction between ammonium and nitrate uptake in phytoplankton. Mar. Ecol. Prog. Ser. 61, 183-201.

Fasham, M.R., H.W. Ducklow and S.M. McKelvie, 1990: A nitrogen based model of plankton dynamics in the oceanic mixed layer. J. Mar. Res., 48, 591-639.

Fenchel, T., 1982: Ecology of heterotrophic microflagellatesII. Bioenergetics and growth. Mar. Ecol. Prog. Ser., 8, 225-231.

Frost, B.W., 1987: Grazing control of phytoplankton stock in the open subarctic Pacific Ocean: a model assessing the
... oceanic regions

persistently rich in

major nutrients are in

some sense iron

limited. 
role of mesozooplankton, particularly the large calanoid copepods, Neocalanus spp. Mar. Ecol. Prog. Ser., 39, $49-68$.

Goldman, J.C. and D.A. Caron, 1985: Experimental studies on an omnivorous microflagellate; implications for grazing and nutrient regeneration in the marine microbial food chain. Deep-Sea Res., 32, 899-915.

Heinbokel, J.F., 1978: Studies on the functional role of tintinnids in the Southern California Bight- $\mathrm{l}$. Grazing and growth rates in laboratory cultures. Mar. Biol., 47, 177 189.

Heinrich, A.K., 1957: The breeding and development of the dominant copepods in the Bering Sea. Trudy Vesesoiuznoe Gidrobiologie Obshchestuo, 8, 143-162.

1962: The life history of plankton animals and seasonal cycles of plankton communities in the oceans. $J$. $d u$ Conseil Int. Explor. Mer, 27, 15-24.

Landry, M.R. and R.P. Hassett, 1982: Estimating the grazing impact of marine microzooplankton. Mar. Biol., 67, 283-288.

and J.M. Lehner-Fournier, 1988: Grazing rates and behaviors of Neocalanus plumchrus: implications for phytoplankton control in the subarctic Pacific. Hydrobiolgia, 167/168. 9-19.

Martin, J.H., 1990: Glacial-interglacial $\mathrm{CO}_{2}$ change: the iron hypothesis. Paleoceanography, 5, 1-13.

1991: Iron, Liebig's law, and the greenhouse. Oceanography, 4. 52-55.

W.W. Broenkow, S.E. Fitzwater and R.M. Gordon, 1990: Yes, it does: a reply to the comment by Banse. Limnol. Oceanogr., 35, 775-777.

and S.E. Fitzwater, 1988: Iron deficiency limits phytoplankton growth in the northeast Pacific subarctic. Nature, 331, 341-343.

R.M. Gordon, S. Fitzwater and W.W. Broenkow, 1989: Vertex: phytoplankton/iron studies in the Gulf of Alaska. Deep-Sea Res., 36, 649-680.

Miller, C.B. and M.J. Clemons, 1988: Revised life history analysis for large grazing copepods in the subarctic $\mathrm{Pa}$ cific Ocean. Prog. Oceanogr., 20. 293-313. and R.D. Nielsen, 1988: Development and growth of large, Calanid copepods in the ocean[ic] subarctic Pacific. Prog. Oceanogr., 24, 275-293.

and SUPER Group, 1988: Lower trophic level production dynamics in the oceanic subarctic Pacific Ocean. Bull. Ocean Res. Inst. Univ. Tokyo, 26, 1-26.

Morel, F.M.M., J.G. Rueter and N.M. Price, 1991: Iron nutrition of phytoplankton and its possible importance in the ecology of ocean regions with high nutrients and low biomass. Oceanography, 4, 56-61.

Parslow, J.S., 1981: Phytoplankton-zooplankton interactions: data analysis and modelling (with particular reference to Ocean Station $\mathrm{P}\left(50^{\circ} \mathrm{N}, 145^{\circ} \mathrm{W}\right)$ and controlled ecosystem experiments). Ph.D. thesis, Univ. British Columbia.

Parsons, T.R. and C.M. Lalli, 1988: Comparative oceanic ecology of the planktonic communities of the subarctic Atlantic and Pacific Oceans. Oceanogr. Mar. Biol. Annu. Rev., 26, 317-359.

Reid, J.L., Jr., 1962: On the circulation, phosphate-phosphorus content and zooplankton volumes in the upper part of the Pacific Ocean. Limnol. Oceanogr., 7, 287-306.

Smith, S.L., 1990: Egg production and feeding by copepods prior to the spring bloom of phytoplankton in Fram Strait, Greenland Sea. Mar. Biol., 106, 59-69.

Warren, B.A., 1983: Why is no deep water formed in the North Pacific? J. Mar. Res., 41, 327-347.

Welschmeyer, N.A. and C.J. Lorenzen, 1985: Chlorophyll budgets: zooplankton grazing and phytoplankton growth in a temperate fjord and the Central Pacific gyres. Limnol. Oceanogr., 30, 1-21.

Wheeler, P.A., D.L. Kirchman, M.R. Landry, and S. A. Kokkinakis, 1989: Diel periodicity in ammonium uptake and regeneration in the oceanic subarctic Pacific: implications for interactions in microbial food webs. Limnol. Oceanogr., 34, 1025-1033.

and S.A. Kokkinakis, 1990: Ammonium recycling limits nitrate use in the oceanic subarctic Pacific. Limnol. Oceanogr., 35, 1267-1278. 